\title{
2,6-Diaminopimelic acid (DAPA) in microbial protein quantification of heifers fed different forage sources
}

\section{Cristovão Colombo de Carvalho Couto Filho ${ }^{1 *}$, Eloísa de Oliveira Simões Saliba ${ }^{2}$, Norberto Mario Rodriguez ${ }^{2}$, Geraldo Sérgio Senra Carneiro Barbosa ${ }^{3}$, Regeane Martins de Freitas ${ }^{2}$, Matheus Pinheiro Diniz Resende ${ }^{2}$}

\footnotetext{
1 Universidade Federal de Minas Gerais, Escola de Veterinária, Programa de Pós-graduação em Zootecnia, Belo Horizonte, MG, Brasil.

${ }^{2}$ Universidade Federal de Minas Gerais, Escola de Veterinária, Departamento de Zootecnia, Belo Horizonte, MG, Brasil.

${ }^{3}$ Universidade Federal de Viçosa, Departamento de Zootecnia, Campus Florestal, Florestal, MG, Brasil.
}

\begin{abstract}
The objective of this study was to evaluate the flow of nitrogenous compounds, protein degradability, rumen degradation of total carbohydrate and organic matter and microbial efficiency in heifers subjected to diets containing corn silage, sugarcane or Tifton. For this purpose, the 2,6-diaminopimelic acid (DAPA) technique was adopted and analytical procedures for amino acids by HPLC were adapted. Six rumen-fistulated Holstein-Zebu heifers with $480 \mathrm{~kg}$ of initial BW and at 24 months of age kept in individual tie stalls were assigned to two $3 \times 3$ Latin squares. Omasal digesta dry matter and microbial dry matter flows were determined using the isolated, purified and enriched lignin (LIPE ${ }^{\circledR}$ ) and DAPA markers, respectively. Isolated bacteria from rumen showed on average $5.84 \mathrm{~g} / 100 \mathrm{~g}$ microbial $\mathrm{N}, 0.25 \mathrm{~g} / 100 \mathrm{~g}$ DAPA in dry matter and 44.61 DAPA: $\mathrm{N}$ ratio. The forage sources did not influence the flows of nitrogen compounds, except for total omasal flow and non-ammonia $\mathrm{N}$ in relation to $\mathrm{N}$ intake for the corn silage diet, for which there was an upward trend compared with the other diets. The degradation of the organic matter and total carbohydrates did not differ, averaging $6.1 \mathrm{~kg} /$ day and $5.2 \mathrm{~kg} /$ day, respectively. The studied forage sources do not influence the flows of nitrogen compounds, except for total omasal flow and non-ammonia $\mathrm{N}$ in relation $\mathrm{N}$ intake for the corn silage diet, for which there is an upward trend compared with the other diets. Protein degradability and microbial efficiency are similar between evaluated diets.
\end{abstract}

Key Words: corn silage, flow of nitrogen compounds, HPLC, microbial efficiency, protein degradability, sugarcane

\section{Introduction}

The protein requirements of ruminants are met through the absorption of amino acids in the intestine, and $60 \%$ of these amino acids come from microbial protein synthesized from the symbiosis between animal and ruminal microbiota. The microbial protein, whose intestinal digestibility is approximately $85 \%$ (Storm and Orskov, 1983), has a relatively constant amino acid profile, containing all amino acids, including the essential ones, in a proportion very close to the ideal, regardless of the protein composition ingested by the animal.

Because of the importance of microbial protein to protein metabolism of ruminants, the quantification of its flow under different physiological and dietary conditions is essential for the requirements of amino acids to be met.

In this study we proposed to evaluate different supplementary forages regularly used aiming to minimize

Received May 2, 2013 and accepted June 23, 2014

Corresponding author: cristovao.couto@ifma.edu.br

${ }^{*}$ Current address: Instituto Federal do Maranhão, São Luís, MA, Brasil.

http://dx.doi.org/10.1590/S1806-92902015000500003

Copyright (@) 2015 Sociedade Brasileira de Zootecnia. This is an Open Access article distributed under the terms of the Creative Commons Attribution Non-Commercial License, which permits unrestricted non-commercial use, distribution, and reproduction in any medium, provided the original work is properly cited. forage seasonality in Central Brazil in order to verify a possible difference in protein synthesis between sources. The sugarcane (Saccharum officinarum, L.) was used because of its peak production and nutritive value coinciding with the period of scarcity of forage. Of the conserved fodder, those selected were corn silage, due to its high content of soluble carbohydrates, which provide a good fermentation pattern, thereby placing it on the level of ideal grass and most used in ensiling processes, and Tifton hay, whose morphophysiological characteristics allow for a more uniform drying, generating a hay that maintains the quality and nutritional value of the fresh forage.

Several microbial markers were used for the abovementioned type of evaluation, each with its advantages and limitations. A noteworthy marker is the 2,6-diaminopimelic acid (DAPA), an amino acid present in the bacterial cell wall, suggested as microbial marker by Synge in 1953, and widely used in experiments in the past for this purpose (Broderick and Merchen, 1992). However, its laboratory quantification by classic chromatography demanded extensive labor time, thus falling into disuse. With the evolution of the technique came the highperformance liquid chromatography (HPLC), recognized by rapid analysis, automation, precision and sensitivity. 
Therefore, this study was undertaken to assess the flow of nitrogen compounds, protein degradability, rumen degradation of total carbohydrates and organic matter and microbial efficiency in heifers subjected to diets containing corn silage, sugarcane or Tifton hay. For this purpose, DAPA technique was used and analytical procedures for amino acids by HPLC were adapted. The technique used for microbial quantification was not the focus of this study, but only a means to achieve the objective.

\section{Material and Methods}

Six rumen-cannulated crossbred Holstein-Zebu heifers with $480 \mathrm{~kg}$ of initial live weight and at 24 months of age were kept in individual tie stalls sheltered and equipped with individual water troughs and troughs for the feed supply.

The experiment lasted 57 days, divided into 3 periods of 19 days. The animals were weighed, identified and dewormed at the beginning of the experiment and kept for 13 days in a period of adaptation to experimental diets and facilities.

Three treatments consisting of different forages in diets were evaluated: corn silage (Zea mays L.), Tifton hay (Cynodon spp.) and sugarcane (Saccharum officinarum, L.). The diets were supplemented with concentrate based on ground corn grain, soybean meal, mineral and vitamin premix, and formulated according to NRC (2001) to be isonitrogenous $(14 \% \mathrm{CP})$, with a forage:concentrate ratio of 75:25, on a dry matter basis (Table 1 ).

The dietary ingredients were weighed and mixed manually twice daily to be delivered at $8.00 \mathrm{~h}$ and $14.00 \mathrm{~h}$ daily as total mixed ration, in an amount sufficient to allow for 5 to $10 \%$ of the offered as daily orts.

The dry matter intake was calculated by multiplying the daily intake of fresh matter of each feed, between days 14 and 19 of each period, by their respective dry matter content, followed by subtracting the daily orts of dry matter. The daily nutrient intake per animal was calculated by multiplying the offered dry matter of each ingredient by its respective nutritional content. Daily orts from the same nutrient were subtracted from the total of nutrients offered per animal.

During the sampling period, samples of forages, concentrates and orts from each animal were collected daily, placed in plastic bags and stored at $-20{ }^{\circ} \mathrm{C}$. At the end of each period, composite samples were made for each feed and also for the orts from the mixture of equal amounts of fresh matter. In the case of the orts, composite samples were made for each heifer per period.

To quantify omasaa flow, the external marker LIPE ${ }^{\circledR}$ was supplied in capsule form at a dosage of $500 \mathrm{mg}$ per heifer daily with two days for adaptation plus the provision

Table 1 - Ingredients and nutrient composition of the experimental diets

\begin{tabular}{llll}
\hline \multirow{2}{*}{ Item } & \multicolumn{3}{c}{ Diets } \\
\cline { 2 - 4 } & Corn silage & Sugarcane & Tifton hay \\
\hline & \multicolumn{3}{c}{$\mathrm{g} \mathrm{kg}^{-1} \mathrm{DM}$} \\
\end{tabular}

Ingredients

Corn silage

Sugarcane

Tifton hay

Ground corn grain

Soybean meal

Minerals and vitamins ${ }^{1}$

Nutrients

Crude protein

Neutral detergent fiber

Ash

Ether extract

Non-fibrous carbohydrates

Total digestible nutrients

Dry matter

${ }^{1}$ Minerals and vitamins (per kg): $150 \mathrm{~g}$ of Ca; $90 \mathrm{~g}$ of P; $17.78 \mathrm{~g}$ of Mg; $15.40 \mathrm{~g}$ of S; $114 \mathrm{~g}$ of Na; $1,500 \mathrm{mg}$ of $\mathrm{Mn} ; 4,000 \mathrm{mg}$ of $\mathrm{Zn} ; 1,200 \mathrm{mg}$ of Cu; $145 \mathrm{mg}$ of Co; $90 \mathrm{mg}$ of I; $38 \mathrm{mg}$ of Se; $900 \mathrm{mg}$ of F; 200,000 IU of vit. A; 50,000 IU of vit. D; $1,500 \mathrm{mg}$ of vit. E.

during the entire sampling period. To collect samples of omasal digesta a set of devices consisting of kitassato, collecting tube and a vacuum pump was used, according to the technique described by Leão (2002). The omasal digesta collections were performed between the days 14 and 16 of each period, according to the following protocol: on the first day collections were made prior to the morning feeding $(0 \mathrm{~h})$ and 6 hours after; on the second day, at the 2 and 8 hours and, on the third day, 4 and 10 hours after it. Omasal digesta samples were frozen at $-20{ }^{\circ} \mathrm{C}$ immediately after collection and kept this way until processing. Composite samples were made for each animal and experimental period. The samples of omasal digesta were dried in a forced air oven at $55{ }^{\circ} \mathrm{C}$ for 96 hours and processed in a mill with a $1 \mathrm{~mm}$ mesh sieve. To estimate the flow of the omasal digesta, LIPE $^{\circledR}$ was used as a marker. The analysis of the $\mathrm{LIPE}^{\circledR}$ marker was performed in a spectrophotometer with light detector in the spectrum of infrared (Saliba et al., 2005). The flows of dry matter and other nutrients in omasal digesta samples were estimated according to the equation of France and Siddons (1986) for external markers:

Omasal flow $=$ Marker dosage mg/day) Marker concentration ( $\mathrm{mg} / \mathrm{g}$ digesta)

On the 19th day of each period, ruminal digesta was collected four hours after feeding for the isolation of bacteria according to technique described by Cecava et al. (1990). The ruminal content was then centrifuged at $170 \mathrm{x} g$ for 5 minutes at $4{ }^{\circ} \mathrm{C}$ for the separation of solids. The precipitate was 
discarded and the supernatant was subjected to a second centrifugation at $17,000 \times g$ for 15 minutes at $4{ }^{\circ} \mathrm{C}$, for precipitating the bacteria. Immediately after, the supernatant was removed and the bacteria were resuspended with $1 \mathrm{M}$ $\mathrm{NaCl}$. A third centrifugation at $17,000 \mathrm{x} g$ for 15 minutes at $4{ }^{\circ} \mathrm{C}$ was performed. The precipitate was then collected with a spatula and washed with acetone. Finally, the precipitate was subjected to oven-drying at a temperature of $45^{\circ} \mathrm{C}$ and subsequently ground in a mortar pestle to turn the material into powder form.

The flow of microbial nitrogen (mic $\mathrm{N}$ ) in omasal digesta was obtained from the ratio between the amount of DAPA in omasal digesta and DAPA: $\mathrm{N}$ on the microorganisms isolated. The microbial efficiency was expressed in different ways: $\mathrm{g}$ microbial nitrogen $/ \mathrm{kg}$ of rumen-degradable organic matter (g mic N/kg RDOM), g microbial nitrogen $/ \mathrm{kg}$ of rumen-degradable total carbohydrates (g mic N/kg RDTC) and $\mathrm{g}$ microbial crude protein $/ \mathrm{kg}$ total digestible nutrients intake (g mic CP/kg TDN).

The separation and quantification of 2,6-diaminopimelic acid was carried out in a liquid chromatograph (HPLC) model Shimadzu LC-10AD (Shimadzu Corporation, Kyoto, Japan) equipped with an ion-exchange column and a fluorescence detector (equipment specifications: communication module CBM - 10A, LC-10AD pumps, injector: SIL-10A, oven, CTO-10A and detector: RF-535).

The analyses of DAPA on the bacterial pellet samples and on the omasal digesta were performed using ion-exchange chromatography system with postcolumn derivatization, using o-phthalaldehyde (OPA) and fluorimetric detection. The standard utilized contained $5.0 \mu \mathrm{g} / \mathrm{L}$ of DL-2,6-diaminopimelic (Fluka AG Buchs SG, Switzerland) in sodium citrate buffer $\mathrm{pH}$ 2.2. The software CLASS-LC10 - LC Workstation allowed access to the chromatograms obtained after analysis of the standard and of the samples and also the determination of the areas of peaks related to the DAPA. The final concentration of DAPA on the samples was obtained from a simple ratio between the area of the standard and area of the sample, as can be seen in the following expression:

Sample concentration $=\underline{\text { Standard concentration } \times \text { Area of the sample }}$ Area of the standard

The analytical conditions in the system were: Column Shim-pack Amino-Na $(4.6 \times 100 \mathrm{~mm})$, Trap Shim-pack ISC-30/S0504 Na, mobile phases A - Citrate buffer pH 3.2, $\mathrm{B}-$ Citrate buffer $\mathrm{pH}$ and $10 \mathrm{C}-\mathrm{NaOH}(0.2 \mathrm{~N})$, gradient elution flow $0.4 \mathrm{ml} / \mathrm{min}$, temperature $60{ }^{\circ} \mathrm{C}$ and detection RF-20Axs Ex $350 \mathrm{~nm}, 450 \mathrm{~nm}$.

For the hydrolysis procedure, $20 \mathrm{mg}$ of crude protein of the bacteria samples and omasum digesta samples were weighed in $30 \mathrm{ml}$ test tubes with screw caps. Then, $10 \mathrm{~mL}$ of $6 \mathrm{~N} \mathrm{HCl}$ were added to the samples. The tubes were sealed off and dried in the oven, where they remained for a period of 22 hours at a temperature of $110 \pm 5^{\circ} \mathrm{C}$ (Bernardi, 2000). After this period, the samples were removed from the oven and left at room temperature until cooling. They were subsequently filtered through a qualitative filter paper and subjected to evaporation. After this procedure, they were resuspended in citrate buffer at $\mathrm{pH} 2.2$ in a $10 \mathrm{~mL}$ volumetric flask, completing the volume. One milliliter of this sample was pipetted into a graduated test tube, and citrate buffer was added to a level high enough to immerse the electrode of the potentiometer, and the $\mathrm{pH}$ of the sample was adjusted to 2.2, using solutions of $4 \mathrm{~N} \mathrm{NaOH}$ and $0.1 \mathrm{~N} \mathrm{HCl}$ for this purpose. After this adjustment, the sample was transferred to a $10 \mathrm{~mL}$ volumetric flask, and its volume was completed. Finally, the sample was subjected to microfiltration using Millex filters type $25 \mathrm{~mm} \mathrm{HV}$ $0.45 \mu \mathrm{M}$ and then transferred to the standard vials used in the automatic injector of the liquid chromatograph.

The samples of food, orts and omasal digesta were pre-dried at $55{ }^{\circ} \mathrm{C}$, ground in a Thomas-Wiley mill with a $1 \mathrm{~mm}$ mesh sieve and stored in plastic containers. The analyses of dry matter (DM), mineral matter (MM), crude protein $(\mathrm{CP})$ and ether extract $(\mathrm{EE})$ contents were performed according to recommendations of the Association of Official Analytical Chemists (AOAC, 1995). The contents of neutral detergent fiber (NDF) were determined according to Van Soest et al. (1991).

The percentages of non-fibrous carbohydrates (NFC) and total carbohydrates (TC) were obtained using the equations proposed by Sniffen et al. (1992): $\mathrm{NFC}=100$ $-(\% \mathrm{NDF}+\% \mathrm{CP}+\% \mathrm{EE}+\% \mathrm{Ash})$ and TC $=100-(\% \mathrm{CP}$ $+\% \mathrm{EE}+\%$ Ash). The content of total digestible nutrients (TDN) of diets were calculated according to the equation described by the NRC (2001), as follows: $\% \mathrm{TDN}=\%$ digestible $\mathrm{CP}+\%$ digestible NDF $+\%$ digestible NFC + $2.25 \% \times \%$ digestible EE.

Regarding the samples of bacterial pellets, not including the 2,6-diaminopimelic acid, they also underwent analysis of DM and $\mathrm{CP}$ according to the procedures described above.

For the study of the flows of nitrogen compounds, protein degradability, rumen degradation of total carbohydrates and organic matter and microbial efficiency through the 2,6-diaminopimelic acid (DAPA), two $3 \times 3$ Latin squares were used in the experiment, according to the following model:

$$
\text { Yijkl }=\mu+\mathrm{Qi}+\mathrm{Dj}+\mathrm{Pk}+\mathrm{N}(\mathrm{i}) \mathrm{l}+\text { eijkl, }
$$

in which: $\mu=$ overall mean; $\mathrm{Q} i=$ effect of Latin square $\mathrm{i}$; $\mathrm{Dj}=$ effect of diet $\mathrm{j} ; \mathrm{Pk}=$ effect of period $\mathrm{k} ; \mathrm{N}(\mathrm{i}) \mathrm{l}=$ effect 
of heifer 1, nested in Latin square i; and eijkl = independent experimental error and with normal distribution, zero mean and $\sigma^{2}$ variance. LIPE $^{\circledR}$ was adopted as the marker of the flow of digesta, due to the good results reported by Couto Filho et al. (2012).

For statistical analysis, all data obtained was subjected to analysis of variance and the means of the diets were compared by SNK test at $5 \%$ probability, on the SISVAR statistical software (Ferreira, 2000).

\section{Results and Discussion}

The microbial $\mathrm{N}$ contents of $6.01,5.55$ and $5.97 \mathrm{~g} / 100 \mathrm{~g}$ DM for corn silage, sugarcane and Tifton hay (Table 2), respectively, are within the range of 4.83 to $10.58 \mathrm{~g} / 100 \mathrm{~g}$ DM reported by Clark et al. (1992) from the compilation of literature data. Another compilation made by Valadares Filho (1995) with results of studies conducted in Brazil showed variations from 81.1 to $95.7 \mathrm{~g} / 100 \mathrm{~g}$ as fed for dry matter and 5.2 to $8.7 \mathrm{~g} / 100 \mathrm{~g}$ DM for total nitrogen compounds, which are also consistent with the values obtained in this study, mainly because these values were obtained in tropical conditions.

In another study, Silva et al. (2007) evaluated diets with Tifton hay and different protein sources for cattle, reporting mean values ranging from 5.14 to $5.55 \mathrm{~g} / 100 \mathrm{~g} \mathrm{DM}$.

The concentrations of DAPA are very similar for the different forage sources (Table 2). The overall mean percentage of $0.25 \%$ DAPA in bacterial DM and 44.61 for the DAPA:N ratio is within the range of 0.14 to $0.44 \%$ reported by Clark et al. (1992), and very close to the average $0.31 \%$ cited by the same authors. In an experiment evaluating different techniques for quantification of microbial synthesis in different breeds of cattle, Valadares Filho et al. (1990) also reported an average value of $0.3 \%$ of DAPA in DM, DAPA: $\mathrm{N}$ ratio of $49 \mathrm{mg} / \mathrm{g}$ of $\mathrm{N}$ in ruminal bacteria, and microbial $\mathrm{N}$ values very similar to those reported here.

For Clark et al. (1992), the origin and amount of crude protein in the diet and the roughage:concentrate ratio of the

Table 2 - Chemical composition of the bacteria isolated from the rumen of heifers fed diets based on corn silage (CS), sugarcane (SC) and Tifton hay (TH)

\begin{tabular}{lrrr}
\hline & \multicolumn{3}{c}{ Diets } \\
\cline { 2 - 4 } Item & \multicolumn{1}{c}{$\mathrm{CS}$} & \multicolumn{1}{c}{$\mathrm{SC}$} & \multicolumn{1}{c}{ TH } \\
\hline Dry matter (g/100 g as fed) & 85.63 & 80.60 & 83.97 \\
Microbial N (g/100 g DM) & 6.01 & 5.55 & 5.97 \\
DAPA (g/100 g DM) & 0.26 & 0.26 & 0.24 \\
DAPA (mg/g DM) & 2.57 & 2.56 & 2.39 \\
DAPA:N (mg/g mic N) & 47.15 & 46.23 & 40.45 \\
\hline
\end{tabular}

DAPA - 2,6-diaminopimelic acid. diet significantly alter this relationship. According to Craig et al. (1987) and Cecava et al. (1990), this relationship varies in the post-feeding period of high-concentrate diets. However, they do not vary when diets with a high roughage proportion are used (Dufva et al., 1982; Olubobokun et al., 1988), a fact that was also observed in the present study.

For Nocek and Russell (1988), the chemical composition of isolated bacteria may be altered according to the conditions of the limiting environment. These authors suggested that the estimations of microbial yield were expressed based on the bacterial $\mathrm{N}$ content, instead of the dry weight of cells. According Clark et al. (1992), the variations in composition of the bacteria can be attributed to the different techniques used to isolate and determine such composition and also to the very variations in their composition.

Ruminal fermentation and flow of microbial and dietary protein to the intestine are affected by feed intake and by the amount and source of energy and protein in the diet. Dietary protein and carbohydrates that are not degraded in the rumen increase the amount of dietary protein that passes to the intestine and may decrease the amount of microbial protein that is synthesized in the rumen, thus leading to variations in the microbial composition.

In the presente study there was a trend towards superiority of the silage diet on the omasal flows of total $\mathrm{N}$ $(\mathrm{P}=0.08)$ and non-ammonia nitrogen (NAN; $\mathrm{P}=0.08)$ in relation to $\mathrm{N}$ intake (Table 3 ). These results can be explained by the differences in the chemical composition (Table 1) of the diets, since the diet of corn silage has a low NDF content, as well as a high content of non-fibrous carbohydrates. Therefore, these factors may have contributed to the increase in these flows to the omasum. These results can also be explained by the lack of synchronism in the rumen degradation of protein and carbohydrates. In the case of the hay, the fiber fraction represents the main source of energy in the rumen and it has slow degradation. As for the sugarcane diet, the lack of synchrony may be justified by the absence of non-protein nitrogen, whose source is important when this type of roughage is used in a diet; however, it was not used in this study as we sought to standardize the protein source used in the different treatments.

Martins et al. (2006), in a comparative study between corn silage and Tifton hay, observed differences in the evaluated parameters. The levels of rumen-degradable organic matter (RDOM), as well as total N, NAN and microbial $\mathrm{N}$ flows were higher in the diets containing corn silage. Several factors can influence the flow of microbial protein, mainly the content and solubility of dietary protein, the $\mathrm{N}$ sources of endogenous origin, the amount of 
digestible organic matter in the diet, the treatment to which dietary protein was subjected, and the absorption of $\mathrm{N}$ by the rumen, particularly in the form of ammonia (Hoover and Stokes, 1991).

The flow of mic N represented, on average, $70.33 \mathrm{~g} / 100 \mathrm{~g}$ of omasal flow of NAN and $69.85 \mathrm{~g} / 100 \mathrm{~g}$ of total N flow in the different treatments. No effect was observed also on the degradability of the diets (Table 3). Similar results were reported by Berchielli et al. (1995b), who studied diets with different roughage:concentrate ratios and, among them, the 80:20, similar to that used in this study (75:25). According to Clark et al. (1992), a reduction in the flow of microbial protein to the small intestine may occur when diets with a high roughage inclusion are used, which may be attributed to the deficiency of readily available energy and to the increase of nitrogen-compounds recycling by rumen microorganisms. The average value of mic $\mathrm{N}$, expressed compared with the NAN in the omasum of the present study, was close to the 75.57 and $73.25 \mathrm{~g} / 100 \mathrm{~g}$ reported by Rode et al. (1985) and Klusmeyer et al. (1990), respectively.

The omasal flow of microbial $\mathrm{N}$ of the diets containing hay averaged $75.66 \mathrm{~g} /$ day (Table 3 ), which is lower than the
$100.6 \mathrm{~g} /$ day obtained by Guimarães et al. (2001) in a study with a roughage:concentrate ratio of $70: 30$, consisting of Tifton hay and cassava waste. This difference may be related to the starch source in the diet. According to Zeoula et al. (2002), the microbial $\mathrm{N}$ flow may increase when corn is replaced by a starch source that is more degradable in the rumen, such as cassava.

The quantities of RDOM and RDTC were not influenced by forage sources, averaging 6.1 and $5.2 \mathrm{~kg} /$ day, respectively (Table 4). Berchielli et al. (1995a) also found no effect of treatments on the amount of RDOM and RDTC. No effect of the experimental diets was observed on microbial efficiency either, when it was expressed as g mic N/kg RDOM, g mic $\mathrm{N} / \mathrm{kg}$ RDTC and g mic CP/kg TDN, whose overall mean values were 16.51, 18.83 and 80.70, respectively (Table 4).

In the CNCPS system (Fox et al., 2004), microbial yield is estimated at $40 \mathrm{~g}$ of cells per $\mathrm{kg}$ of rumen-degradable total carbohydrates, a value obtained from the maintenance requirements of microorganisms and their respective growth rates (Russell et al., 1992). These values are satisfactorily accurate for higher dry matter omasal flows, which are a result of nutrition plans superior to those of the present study.

Table 3 - Omasal flow of nitrogen compounds (g/day) and degradability of protein in diets based on corn silage (CS), sugarcane (SC) and Tifton hay $(\mathrm{TH})$

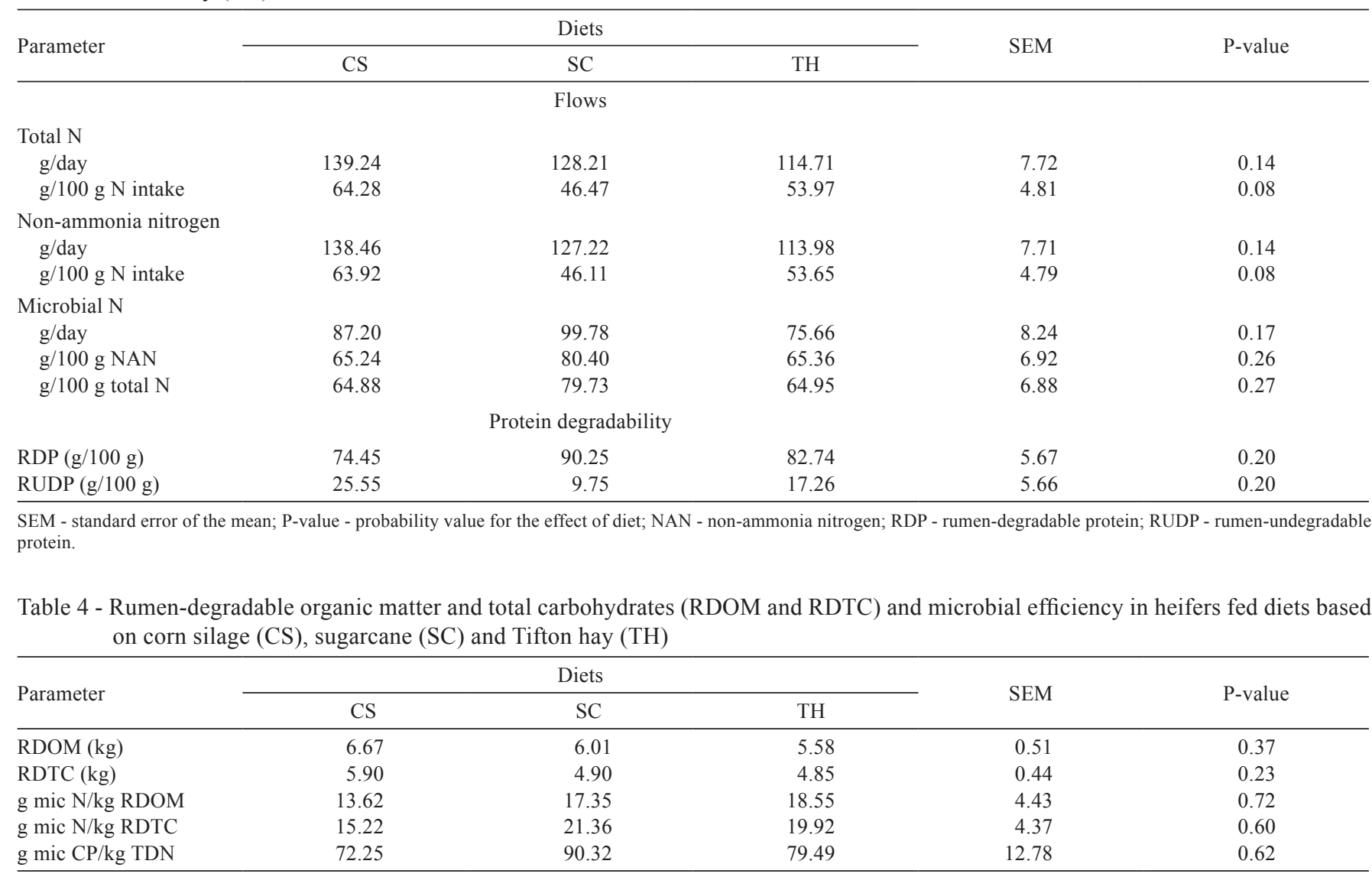

SEM - standard error of the mean; P-value - probability value for the effect of diet. 
In the case of low levels of intake, overestimated values of the microbial $\mathrm{N}$ flow are predicted. The mean values found for the efficiency of microbial synthesis in $\mathrm{g}$ mic $\mathrm{CP} /$ $\mathrm{kg}$ TDN were lower than the 130 recommended by NRC (2001), irrespective of diet. For Dewhurst et al. (2000) and NRC (2001), the availability of energy in the rumen and $\mathrm{N}$ values are the factors that most limit microbial growth. According to these authors, to enhance fermentation and microbial protein synthesis in the rumen, it is necessary to synchronize the availability of fermentable energy and rumen-degradable $\mathrm{N}$.

The estimated values of microbial efficiency expressed in relation to RDOM and RDTC for the hay diet were greater than those obtained by Silva et al. (2007), working with Tifton hay supplemented with soybean meal, among the different nitrogen sources evaluated, but lower than the results reported by Berchielli et al. (1995a), who evaluated different markers, including DAPA, and different roughage:concentrate ratios, and Cabral et al. (2008), who evaluated different forages. These same authors, utilizing corn silage, reported slightly greater efficiencies than the results obtained in the current study.

Taking into account the ruminal availability of energy and nitrogen as the determinant factors of microbial growth, high roughage proportions such as that used herein (75:25) can lead to reduction of energy availability and increase in the recycling of nitrogen compounds by rumen microorganisms. Thus, the decrease in the passage of microbial protein to the small intestine may have contributed to the lower values of microbial protein synthesis efficiency in this experiment. Therefore, the high roughage:concentrate ratio used in this study may have influenced the microbial growth by limiting it. Furthermore, the similarity between the roughage:concentrate ratio (75:25) of all experimental diets may have resulted in the absence of significant effect on the microbial efficiency among the many roughage sources used in this study. For Clark et al. (1992), faster rates of microbial growth are attributed to the greater availability of nutrients, associated with a faster passage of microorganisms to the abomasum, leading to the reduction of maintenance requirement of rumen macrobiotic and, consequently, an increased microbial efficiency.

An important criticism about the studies with microbial protein synthesis is regarding the calculations of the microbial compounds flows, taking into account the percentage of nitrogen in relation to organic matter rather than dry weight. Obviously, potential contamination of bacteria with saline solution during the isolation procedures can occur, and when that happens the $\mathrm{N}$ content is normally used in relation to organic matter. Therefore, this emphasizes the need for standardizing these calculations, because as they are based on the dry matter, they provide significantly different results for both the nitrogen-compound flow and the microbial efficiencies as compared with those derived from organic matter. The consequence of this is the difficulty in comparing results of different studies.

\section{Conclusions}

The studied forage sources do not influence the flows of nitrogen compounds, except for total omasal flow and nonammonia nitrogen in relation to nitrogen intake for the corn silage diet, for which there is an upward trend compared with the other diets.

The protein degradability, the degradation of organic matter and total carbohydrates in the rumen, and the efficiency of microbial synthesis are similar among the evaluated diets.

\section{Acknowledgments}

The authors would like to thank Fundação de Amparo à Pesquisa do Estado de Minas Gerais (FAPEMIG) for the financial support to this research, and Fundação de Amparo à Pesquisa e ao Desenvolvimento Científico e Tecnológico do Maranhão (FAPEMA) for the partial support to the publication of this research.

\section{References}

AOAC - Association of Official Analytical Chemists. 1995. Official methods of analysis. 16th ed. AOAC, Washington, DC.

Berchielli, T. T.; Rodriguez, N. M.; Andrade, P. and Sampaio, I. B. M. 1995a. Eficiência de síntese de proteína microbiana estimada por diferentes marcadores microbianos. Revista da Sociedade Brasileira de Zootecnia 24:800-809.

Berchielli, T. T.; Rodriguez, N. M.; Gonçalves, L. C. and Sampaio, I. B. M. 1995b. Fluxo de nitrogênio duodenal e degradabilidade ruminal do nitrogênio da dieta estimado por meio de três marcadores microbianos. Revista da Sociedade Brasileira de Zootecnia 24:810-819.

Bernardi, C. A. 2000. Preparo de hidrolisados protéicos e análise de aminoácidos por duas metodologias. Tese (D.Sc.). Centro de Ciências Agrárias/Universidade Federal de Santa Catarina, Florianópolis.

Broderick, G. A. and Merchen, N. R. 1992. Markers for quantifying microbial protein synthesis in the rumen. Journal of Dairy Science 75:2618-2632.

Cabral, L. S.; Valadares Filho, S. C.; Detmann, E.; Zervoudakis, J. T.; Souza, A. L. and Veloso, R. G. 2008. Eficiência microbiana e parâmetros ruminais em bovinos alimentados com dietas à base de volumosos tropicais. Revista Brasileira de Zootecnia 37:919-925.

Cecava, M. J.; Merchen, N. R.; Gay, L. C. and Berger, L. L. 1990. Composition of ruminal bacteria harvested from steers as 
influenced by dietary energy level, feeding frequency, and isolation techniques. Journal of Dairy Science 73:2480-2488.

Clark, J. H.; Klusmeyer, T. H. and Cameron, M. R. 1992. Microbial protein synthesis and flows of nitrogen fractions to the duodenum of dairy cows. Journal of Dairy Science 75:2304-2323.

Couto Filho, C. C. C.; Saliba, E. O. S. S.; Rodriguez, N. M.; Barbosa, G. S. S.; Martins, R. and Silva, F. A. 2012. Quantificação da síntese protéica microbiana por meio do ácido 2,6-diaminopimélico (DAPA) obtido por cromatografia líquida de alta eficiência, em dietas com fontes volumosas diferentes. In: Anais da 49a Reunião Anual da Sociedade Brasileira de Zootecnia. Sociedade Brasileira de Zootecnia, Brasília.

Craig, W. M.; Brown, D. R.; Broderick, G. A. and Ricker, D. B. 1987. Post-prandial composition changes of fluid and particle-associated ruminal microorganisms. Journal of Animal Science 65:1042-1048.

Dewhurst, R. J.; Davies, D. R. and Merry, R. J. 2000. Microbial protein supply from the rumen. Animal Feed Science and Technology 85:1-21.

Dufva, G. S.; Bartley, E. E.; Arambel, M. J.; Nagaraja, T. G.; Dennis, S. M.; Galitzer S. J. and Dayton, A. D. 1982. Diaminopimelic acid content of feeds and rumen bacteria and its usefulness as a rumen bacterial marker. Journal of Dairy Science 65:1754-1759.

Ferreira, D. F. 2000. Análises estatísticas por meio do Sisvar para Windows versão 4.0. p.255-258. In: 45a Reunião Anual da Região Brasileira da Sociedade Internacional de Biometria. UFSCar, São Carlos, SP.

Fox, D. G.; Tedeschi, L. O.; Tylutki, T. P.; Russell, J. B.; Van Amburgha, M. E.; Chasea, L. E.; Pell, A. N. and Overton, T. R. 2004. The Cornell Net Carbohydrate and Protein System model for evaluating herd nutrition and nutrient excretion. Animal Feed Science and Technology 112:29-78.

France; J. and Siddons, R. C. 1986. Determination of digesta flow by continuous marker infusion. Journal of Theoretical Biology 121:105-119.

Guimarães, K. C.; Branco, A. F.; Zeoula, L. M.; Alcalde, C. R.; Fregadolli, F. L. and Caldas Neto, S. F. 2001. Efeito do período experimental sobre a fermentação e eficiência de síntese microbiana em bovinos alimentados com dois níveis de volumosos. Revista Brasileira de Zootecnia 30:880-887.

Hoover, W. H. and Stokes, S. R. 1991. Balancing carbohydrates and proteins for optimum rumen microbial yield. Journal of Dairy Science 74:3630-3644.

Klusmeyer, T. H.; McCarthy, R. D. and Clark, J. H. 1990. Effects of source and amount of protein on ruminal fermentation and passage of nutrients to the small intestine of lactating cows. Journal of Dairy Science 73:3526-3537.

Leão, M. I. 2002. Metodologias de coletas de digestas omasal e abomasal em novilhos submetidos a três níveis de ingestão: consumo, digestibilidade e produção microbiana. Tese (D.Sc.). Escola de Veterinária/Universidade Federal de Minas Gerais, Belo Horizonte.

Martins, A. S.; Vieira, P. F.; Berchielli, T. T.; Prado, I. N. and Garcia, J. A. S. 2006. Eficiência de síntese microbiana e atividade enzimática em bovinos submetidos à suplementação com enzimas fibrolíticas. Revista Brasileira de Zootecnia 35:1194-1200.

NRC - National Research Council. 2001. Nutrient requirements of dairy cattle. 7 th ed. National Academy Press, Washington, DC.
Nocek, J. E. and Russell, J. B. 1988. Protein and energy as an integrated system. Relationship of ruminal protein and carbohydrate availability to microbial synthesis and milk production. Journal of Dairy Science 71:2070-2107.

Olubobokun, J. A.; Craig, W. M. and Nipper, W. A. 1988. Characteristics of protozoal and bacterial fractions from microorganisms associated with ruminal fluid or particles. Journal of Animal Science 66:2701-2710.

Rode, L. M.; Weakley, D. C. and Satter, L. D. 1985. Effect of forage amount and particle size in diets of lactating dairy cows on site of digestion and microbial synthesis. Canadian Journal of Animal Science 65:101-111.

Russell, J. B.; O’Connor, J. D.; Fox, D. G.; Van Soest, P. J. and Sniffen, C. J. 1992. A net carbohydrate and protein system for evaluation cattle diets: ruminal fermentation. Journal of Animal Science 70:3551-3581.

Saliba, E. O. S.; Nanjaro, A. and Ferreira, W. M. 2005. Avaliação da lignina de madeira moída do Pinus e da lignina purificada e enriquecida do Eucaliptus grandis $\left(\mathrm{LIPE}^{\circledR}\right)$, como indicadores externos em experimentos de digestibilidade aparente para coelhos em crescimento. p.23-25. In: Anais da $1^{\text {a }}$ Telecoferência sobre Indicadores em Nutrição Animal. Escola de Veterinária/UFMG, Belo Horizonte.

Silva, E. A.; Berchielli, T. T.; Reis, R. A.; Fernandes, J. J. R.; Sato, K. J. and Paes, J. M. V. 2007. Teores de proteína bruta para bovinos alimentados com feno de capim-tifton 85: parâmetros ruminais, eficiência de síntese microbiana e degradabilidade in situ. Revista Brasileira de Zootecnia 36:225-237.

Sniffen, C. J.; O’Connor, J. D.; Van Soest, P. J.; Fox, D. G. and Russell, J. B. 1992. A net carbohydrate and protein system for evaluation cattle diets. II. Carbohydrate and protein availability. Journal of Animal Science 70:3562-3577.

Synge, R. L. M. 1953. Note on the occurrence of diaminopimelic acid in some intestinal microorganisms from farm animals. Journal of General Microbiology 9:407-409.

Storm, E. and Orskov, E. R. 1983. The nutritive value of rumen micro-organisms in ruminants. 1. Large scale isolation and chemical composition of rumen micro-organisms. British Journal of Nutrition 50:463-470.

Valadares Filho, S. C.; Silva, J. F. C.; Leão, M. I.; Sant'Anna, R. and Valadares, R. F. D. 1990. Eficiência de síntese microbiana em novilhos holandeses, nelores e búfalos mestiços, obtida por diferentes métodos. Revista da Sociedade Brasileira de Zootecnia 19:424-430.

Valadares Filho, S. C. 1995. Eficiência de síntese de proteína microbiana, degradação ruminal e digestibilidade intestinal da proteína bruta em bovinos. p.355-388. In: Anais do Simpósio Internacional sobre Exigências Nutricionais de Ruminantes. Universidade Federal de Viçosa, Viçosa, MG.

Van Soest, P. J.; Robertson, J. B. and Lewis, B. A. 1991. Methods for dietary fiber, neutral detergent fiber, and nonstarch polyssacharides in relation to animal nutrition. Journal of Dairy Science 74:3583-3597.

Zeoula, L. M.; Caldas Neto, S. F.; Branco, A. F.; Prado, I. N.; Dalponte, A. O.; Kassies, M. and Fregadolli, F. L. 2002. Mandioca e resíduos das farinheiras na alimentação de ruminantes: $\mathrm{pH}$, concentração de $\mathrm{N}_{-} \mathrm{NH}_{3}$ e eficiência microbiana. Revista Brasileira de Zootecnia 31:1582-1593. 